\title{
[Retracted article] Gastric and jejunal histopathological changes in patients undergoing bariatric surgery
}

Rosemary Simões Nomelini RODRIGUES, Élia Cláudia de Souza ALMEIDA, Júverson Alves TERRA JÚNIOR, Lucinda Calheiros GUIMARÃES, Ana Cristina da Rocha DUQUE and Renata Margarida ETCHEBEHERE

The Editorial Board of Archives of Gastroenterology, ISSN 1678-4219 online, decided, after analysis, to retract the article following:

Rodrigues RSN, Almeida ECS, Terra Júnior JA, Guimarães LC, Duque ACR, Etchebehere RM. Gastric and jejunal histopathological changes in patients undergoing bariatric surgery. Arq Gastroenterol. 2017,54(1):75-8. doi: 10.1590/S0004-2803.2017v54n1-15.

The submission process is based on the authors' ethics in ensuring exclusivity to a single journal. There are no means of submission and publication duplicity control in two jornals in near dates. 